\title{
MANGANESE MINERALISATIONS AT THE BASE OF MIOCENE SEDIMENTS IN NORTHERN SARDINIA (ITALY)
}

\author{
Fadda S. ${ }^{1}$, Fiori M. ${ }^{1}$, Pretti S. ${ }^{2}$, and Valera P. $^{2}$ \\ ${ }^{1}$ Istituto di Geologia Ambientale e Geoingegneria del CNR, 09100 Cagliari, Italy, \\ sfadda@unica.it,fiori@unica.it \\ ${ }^{2}$ Dipartimento di Geoingegneria e Tecnologie Ambientali, Università di Cagliari, Italy. \\ paolo@paolov.net
}

\begin{abstract}
During the eastward drift of the Palaeozoic-Mesozoic block formed by Sardinia and Corsica in the Oligocene-Miocene, calc-alkaline volcanism developed mostly in the western part of the island. Most Tertiary metallogenic phoenomena are related to hydrothermal activity associated with this volcanism. Following volcanic and related hydrothermal activity, sediments were deposited during the Oligocene-Miocene as a consequence of a marine transgression. The basal part of this series is clastic and includes elements derived from erosion of unaltered volcanics as well as hydrothermally altered rocks and hydrothermal vein quartz. Inside the Tertiary volcanics manganese ore-minerals occur as nodules, veinlets, and stockworks and mainly include Mn and Fe oxides; quartz in different forms is the most common gangue mineral. The mineralisations at the contact between volcanics and Miocene sediments are the most homogeneous, the ore-minerals occur in the cement, but also as fairly continuous thin beds, nodules and veinlets containing pyrolusite, frequent ramsdellite, less frequent manganite, psilomelane, cryptomelane-manjiroite, rare ranciéite, and todorokite. The nature of the ore-bearing beds indicate a near-shore clastic environment along the ancient coastal lines of the Miocene sea. Genetic considerations point to a supergenic transport and redeposition after erosion of primary dispersion and residual concentrations of Mn in the volcanics.
\end{abstract}

Key words: sedimentary manganese, volcanism, metallogeny, Sardinia.

\section{Introduction}

During the detachment and eastward drift towards Italy of the Sardinian-Corsican massif, extensive conditions led to an important rifting phase, which opened the presently NS-striking trough, the so called Fossa Sarda, cutting the entire island of Sardinia (Fig. 1). Related to these conditions, and within the resultant graben, an intense volcanic activity took place from the Upper Oligocene to the Middle Miocene in the western half of this island, with mostly extrusive products of calc-alkaline affinity typical of plate convergence zones (Cherchi and Montadert, 1982). Three main volcanic cycles developed, each characterized by initial, mainly andesitic lavas followed by more acidic pyroclastic activity with intervals of epiclastic rocks. The earlier volcanic products occurred in southwestern Sardinia between 29 and 27 My ago, with episodes of basaltic and andesitic lavas forming flows, domes, and dikes. The following, mostly explosive phase lasted from 20 to $18 \mathrm{My}$ ago and developed particularly in central and northern Sardinia with ignimbrites and minor flows 


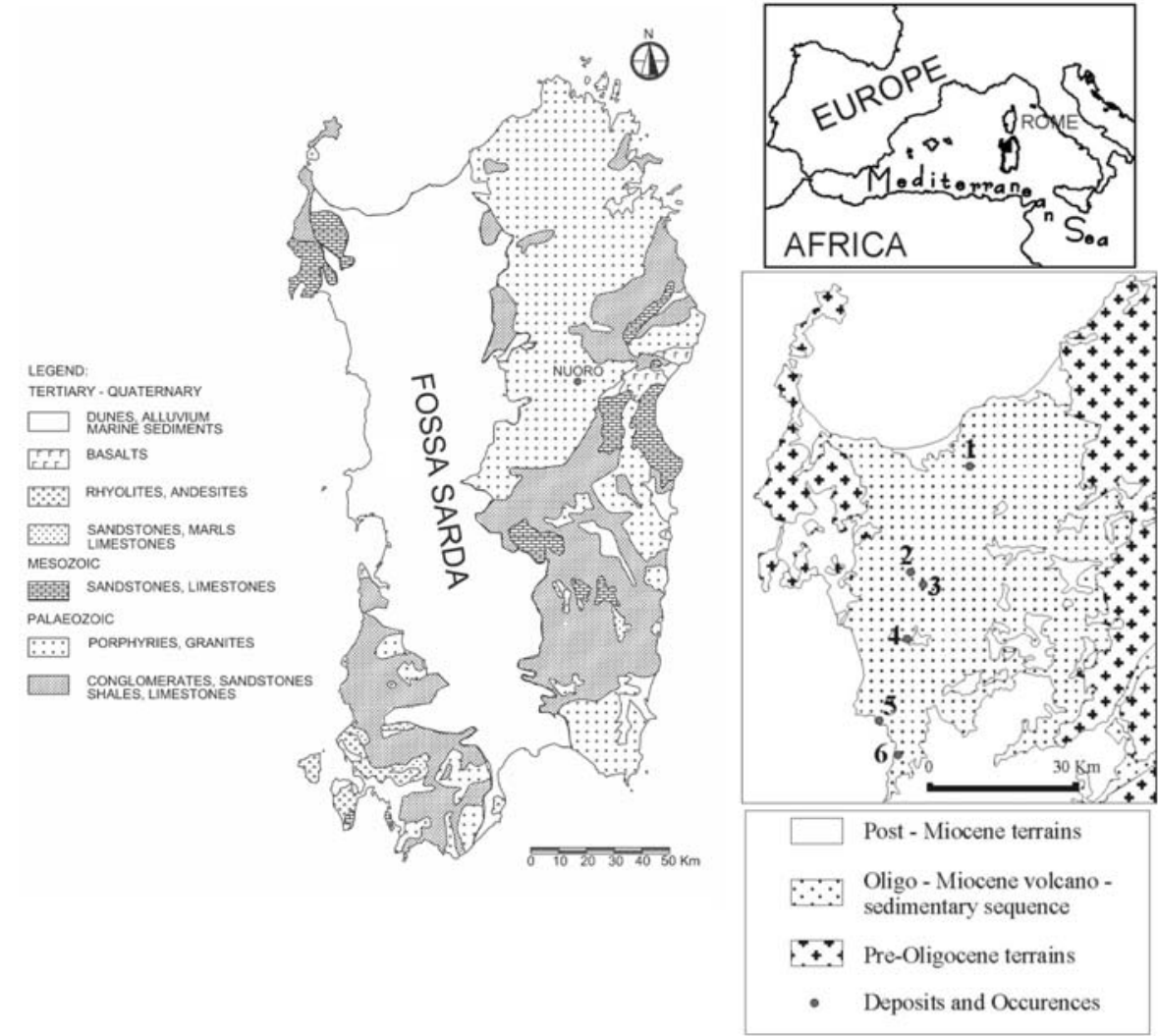

Fig. 1: Left: Geological sketch map of Sardinia showing the Fossa Sarda trough. Right: Geological sketch map of the north-western Sardinia showing the distribution of manganese occurrences: 1) Corona de Corvu, 2) Monte Jorzi, 3) Sos Aghedos, 4) Alghentalzos, 5) Giolzi Moro, 6) Tippiri.

of rhyolitic and dacitic composition. The latest products of this mostly subaerial volcanism, from 14 to $13 \mathrm{My}$, are represented by intercalated epiclastic and ash flow beds (Coulon, 1977). During the waning phases of this volcanism, hydrothermal activity developed episodically, producing local alteration and precious- and base-metal mineralizations mainly high- and low-sulfidation epithermal veins and stockworks containing gold, pyrite, sphalerite, galena, and minor chalcopyrite (Garbarino et al., 1991). Closely linked with this calc-alkaline magmatism, manganese deposits also formed, mainly within the volcanic products, and subordinately in the Miocene beds immediately resting upon these volcanics. At the same time, the gradual dipping of the longitudinal trough initiated a marine trangression progressing from the south to the north across the island, and then continental clastic sediments were deposited. The final submarine Tertiary calc-alkaline volcanic rocks (around 11 My) are interbedded with these sediments, especially within the central part of the rift. The terrigenous materials show textural and compositional immaturity, commonly show lenticular bedding and locally exibit sedimentary structures indicative of low-energy depositional environments, such as lamination. The basal conglomerates and sandstones of the sequence are characterized by erosion products that include metals mobilized from unaltered volcanics as well as from hydrothermally altered rocks and the newly formed hydrothermal deposits. Literature records concerning occurrences 
of metallic minerals in Tertiary sedimentary rocks of Sardinia are rare. The best and long-known are manganese oxides bodies in NW Sardinia, only recently recognised as near-shore deposits, which were explored and mined to a minor extent.

\section{Geological setting and stratigraphy}

The sedimentary basins under study represent the northern part of the Tertiary trough cutting the island of Sardinia from north to south (Fig. 1). In this area, the graben filling is formed of ignimbritic lava flows dipping toward the centre of the trough, with numerous faults connected to tectonic events of Miocene age. The region is characterized by the presence of volcanic rocks generated during the calc-alkaline volcanism, and formed of andesites, dacites, rhyolites and ignimbrites (Coulon, 1977). The sedimentary filling consists of marginal fanglomerates and central lacustrine sediments. Calcalkaline volcanics and tuffites are interlayered with continental sediments. The Oligocene-Aquitanian age of the sediments and volcanic rocks confines the development of the basin to this time span. The post-volcanic sedimentary rocks are mixed siliciclastic-carbonate sequences from terrestrial and coastal sands, shelf carbonates and marls. Silty marlstones of Late Burdigalian-Early Langhian age characterize the central part of the main basin, whereas variabile siliciclastic and carbonate sequences developed at its margins and at the confluence with the smaller grabens (Martini et al., 1992). The sedimentary sequence rests unconformably upon volcaniclastic beds (tuff and cinder) interlayered with freshwater limestones and black cherts. At the top, the most continuous sections have been preserved either under thick carbonates, or under 5 to $30 \mathrm{~m}$-thick Pliocene-Pleistocene lava flows, which cap the hills. However, the layercake disposition of the strata allows the visual correlation of several Units across the basins and the overall paleosetting of the sediments can be reasonably well reconstructed (Mazzei and Oggiano, 1990). Five informal lithostratigraphic units have been distinguished: the Lower Sands, of continental fluviatile-deltaic origin are followed upward by the Lower Limestones which mark the first marine transgression of the whole area during the uppermost Burdigalian. A sudden deepening of the basin is marked by the Marly Arenaceous unit that shows features indicative of an environment deeper than that of the Lower Limestones and occurs primarily in the deepest central part of the main graben; a sandier variety is also present on parts of the basin-edge area. The Upper Sands, again of deltaic-fluviatile origin, have been ascribed to the Upper Langhian - Lower Serravallian interval. They rest on the Marly Arenaceous Unit through an erosional contact. Finally, the Upper Limestone lies unconformably on both the Upper Sands and the Marly Arenaceous Unit; this lithostratigraphic unit marks a second marine transgression, which probably occurred during the Lower Messinian.

A major transgression can be established in the lower part of the sequence, from continental sands to marine marly and algal limestone units. The environment represented by these Lower Sands ranges from braided fluvial deposits to lowland paralic settings, to fluvio-lacustrine and fluvio-marine deltas, to barred shores containing fossiliferous banks. The Lower Sands are characterized by the vertical and lateral transitions of gravel to sandy continental facies grading up into marine sands and sandy carbonate. These sandstones may be derived from numerous sources, Tertiary volcanites, Palaeozoic granites, schists and gneisses. Gravel has two types of occurrences: one type consists of reddish, sandy, pebble-to-small-boulder conglomerate, well cemented and locally showing well developed fabric; the other consists of sandy, poorly cemented, fairly well-sorted conglomerate, with plane- and cross-beds. In both cases, the gravels represent braided-stream deposits. Siliciclastic deposits vary from coarse, conglomeratic in places, unfossiliferous, massive to locally cross-bedded lithic sands, to purer quartz-feldsphatic sands. Locally, the sands are calcareous and rarely include large-scale foresets. These lower continental facies were gradually drowned by a transgressive sea, 
and their topset materials were reworked into bars and plains, and finally a carbonate environment was established.

\section{Mode of occurrence, mineralogy and chemistry of Mn-ore}

All the exploration and mining operations on Mn ores have long ceased, and the old mining works are seldom accessible. Thus, only a few small excavations and outcrops have been surveyed and sampled, and most of the samples are from old dumps. The mineralisations inside Tertiary volcanics are the most widespread, Mn minerals occur as nodules, veinlets, and stockworks. Besides the dominant pyrolusite, ubiquitosus, the ore-mineral assemblages commonly include ranciéite, manjiroite and cryptomelane. Among the Fe minerals goethite, often accompanied by hematite, is highly frequent. The gangue mineral is quartz, that commonly occurs as chalcedony or jasper, finely disseminated in the ore, or as chalcedony veins impregnated with Mn oxides.

The mineralisations at the contact Tertiary volcanics - Miocene sediments are the most homogeneous: their attitude is always stratiform and concordant. Figure 1 shows the distribution of manganese occurrences at the contact Tertiary volcanics - Miocene sediments in the northern regions of Anglona - Logudoro and Meilogu - Planargia (Marcello et al., 2004).

The stratigraphy of the manganese mineralized formations is uniform along the near-shore zones and coastal lines, with only minor variations. The ore minerals are distributed along the shoreline, with the bulk contained in a conglomeratic stratiform layer. The most important character common to all these bodies is their occurrence within clastic (clasts from the underlying volcanics), mainly conglomeratic, suites. Their cover (that is missing only at Giolzi Moro) is a Miocene carbonatic platform series. The ore minerals occur in the cement, but also as fairly continuous thin beds, nodules and veinlets. The Mn-bearing ore minerals occur both well crystallized, compact and of metallic appearance, and earthy, with loose fabric and deep-black colour. To the earthy strata fossiliferous (fish teeth) pelitic lenses are commonly associated. Several "burrows" can be observed. Their cilyndric shape is filled with the ore minerals in fibrous structures with radial symmetry, along with clastic elements.

The ore mineral assemblage is monotonous: ubiquitous pyrolusite (pure $\mathrm{MnO}_{2}$ tetragonal), frequent ramsdellite $\left(\mathrm{MnO}_{2}\right.$ orthorombic), less frequent the manganese hydroxide manganite $(\mathrm{MnOOH})$, psilomelano ( $\mathrm{Ba}, \mathrm{K}, \mathrm{Mn}, \mathrm{Co})_{2} \mathrm{Mn}_{5} \mathrm{O}_{10} \cdot \mathrm{xH}_{2} \mathrm{O}$ ), and cryptomelane-manjiroite $(\mathrm{Na}, \mathrm{K})_{1-2} \mathrm{Mn}_{8} \mathrm{O}_{16}$. $\left.\mathrm{xH}_{2} \mathrm{O}\right)$, rare ranciéite $\left.(\mathrm{Ca}, \mathrm{Mn}) \mathrm{Mn}_{4} \mathrm{O}_{9} \cdot 3 \mathrm{H}_{2} \mathrm{O}\right)$ and todorokite $\left(\mathrm{Na}, \mathrm{Ca}, \mathrm{K}, \mathrm{Mn}^{2+}\right)\left(\mathrm{Mn}^{4+}, \mathrm{Mn}^{2+}\right.$, $\mathrm{Mg})_{6} \mathrm{O}_{12} \cdot 3 \mathrm{H}_{2} \mathrm{O}$. The nature of the ore-bearing beds indicates a near-shore clastic environment, followed by a slightly deeper one. All points to a supergenic deposition controlled by ancient coastal lines, like in the better known, quite bigger occurrences of Western Europe and Northern Africa.

The tetravalent oxides pyrolusite and ramsdellite are the most common ore minerals for which precipitation involves oxidation of the $\mathrm{Mn}^{2+}$ in solution to $\mathrm{Mn}^{4+}$ possibly favoured by the presence of a pre-existing surface of iron oxide or hydroxide. In this model, the dissolved metal carried by surface waters under oxidizing conditions, precipitated at the shoreline owing to a rise in $\mathrm{pH}$ from 6 to 8 , typical of the fresh water to marine transition. The presence of psilomelane, cryptomelane, todorokite and rancieite suggests that somehow $\mathrm{K}, \mathrm{Ba}, \mathrm{Ca}$ and $\mathrm{Na}$, originated from the erosion of hydrothermally altered volcanic source rocks in the continental drainage area, must have been present at the time of deposition. However, where slightly more reducing conditions prevailed in the muds of even shallow marine environments, tetravalent manganese was gradually reduced to the trivalent state in the manganite-rich ores found in limited parts of these deposits. Trace elements such as $\mathrm{Ni}$, $\mathrm{W}, \mathrm{Sn}, \mathrm{Ag}$ and others may be adsorbed successfully on to hydrated colloidal $\mathrm{MnO}_{2}$ at $\mathrm{pH} 7-8$. The 
Table 1. Major elements were determined by flame atomic absorption and emission spectrometry (FAAS/FAES). Trace elements by inductively coupled plasma-atomic emission spectrometry (ICP-AES). For mineral identification, powdered samples were mounted on glass slides and subjected to X-ray diffractometry (XRD) on a Rigaku Geigerflex fully automated apparatus. The assignments of peaks were from the JCPDS File (1985).

\begin{tabular}{|c|c|c|c|c|c|c|c|c|c|c|c|}
\hline Localities & District & Type & Minerals & $\begin{array}{c}\mathrm{MnO} \\
\%\end{array}$ & $\begin{array}{c}\mathrm{Fe}_{2} \mathrm{O}_{3} \\
\%\end{array}$ & $\begin{array}{c}\mathrm{SiO}_{2} \\
\%\end{array}$ & $\begin{array}{l}\mathrm{Ba} \\
\%\end{array}$ & $\begin{array}{c}\mathrm{Ni} \\
\mathrm{ppm}\end{array}$ & $\begin{array}{c}\text { W } \\
\text { ppm }\end{array}$ & $\begin{array}{c}\mathrm{Sn} \\
\mathrm{ppm}\end{array}$ & $\begin{array}{c}\text { Ag } \\
\text { ppm }\end{array}$ \\
\hline $\begin{array}{c}\text { Corona } \\
\text { De Corvu }\end{array}$ & Turritano & Stratiform & $\begin{array}{l}\text { Pyrolusite } \\
\text { Ramsdellite } \\
\text { Manjiroite } \\
\\
\text { Ranciéite } \\
\text { Psilomelane* } \\
\text { Criptomelane* }\end{array}$ & $\begin{array}{c}50.6 \\
74.36 \\
47.50 \\
68.68 \\
\\
32.1 \\
33.17 \\
50.59\end{array}$ & \begin{tabular}{|c}
4.58 \\
0.28 \\
0.85 \\
0.86 \\
\\
4.0 \\
6.14 \\
\\
1.7
\end{tabular} & $\begin{array}{c}18.3 \\
2.4 \\
3.5 \\
6.2 \\
\\
25.8 \\
29.8 \\
\\
35\end{array}$ & $\begin{array}{c}2.1 \\
0.20 \\
0.51 \\
0.22 \\
\\
1.3 \\
1.5 \\
0.3\end{array}$ & $\begin{array}{c}55 \\
45 \\
45 \\
110 \\
\\
65 \\
30 \\
18\end{array}$ & $\begin{array}{l}<50 \\
<50 \\
<50 \\
<50 \\
\\
<50 \\
<50 \\
\\
145\end{array}$ & & \\
\hline $\begin{array}{c}\text { Monte } \\
\text { Jorzi }\end{array}$ & Meilogu & Stratiform & $\begin{array}{l}\text { Pyrolusite } \\
\text { Todorokite* }\end{array}$ & $\begin{array}{l}52.1 \\
48.6\end{array}$ & $\begin{array}{c}1.9 \\
0.68\end{array}$ & $\begin{array}{c}10.4 \\
6.8\end{array}$ & $\begin{array}{l}0.45 \\
0.45\end{array}$ & $\begin{array}{c}103 \\
58\end{array}$ & $\begin{array}{l}<20 \\
<20\end{array}$ & $\begin{array}{l}80 \\
75\end{array}$ & $\begin{array}{l}<1.5 \\
<1.5\end{array}$ \\
\hline $\begin{array}{c}\text { Sos Aghe- } \\
\text { dos }\end{array}$ & Meilogu & Stratiform & $\begin{array}{l}\text { Pyrolusite } \\
\text { Manganite } \\
\text { Groutite* }\end{array}$ & $\begin{array}{l}24.2 \\
65.5\end{array}$ & $\begin{array}{l}1.9 \\
1.0\end{array}$ & $\begin{array}{c}32.1 \\
8.6\end{array}$ & $\begin{array}{l}0.42 \\
0.16\end{array}$ & $\begin{array}{l}21 \\
96\end{array}$ & $\begin{array}{l}<20 \\
<20\end{array}$ & $\begin{array}{c}55 \\
110\end{array}$ & $\begin{array}{l}<1.5 \\
<1.5\end{array}$ \\
\hline $\begin{array}{l}\text { Alghental- } \\
\text { zos }\end{array}$ & Logudoro & Stratiform & $\begin{array}{l}\text { Manganite } \\
\text { Groutite* }\end{array}$ & $\begin{array}{c}85.2 \\
66.5 \\
52.3 \\
66\end{array}$ & $\begin{array}{c}0.14 \\
3.13 \\
1.90 \\
1.2\end{array}$ & $\begin{array}{c}2.1 \\
5.2 \\
13.2 \\
8.8\end{array}$ & $\begin{array}{l}0.77 \\
0.09 \\
0.19 \\
0.21\end{array}$ & $\begin{array}{c}20 \\
330 \\
40 \\
95\end{array}$ & $\begin{array}{l}<20 \\
<20 \\
<20 \\
<20\end{array}$ & $\begin{array}{c}15 \\
105 \\
90 \\
100\end{array}$ & $\begin{array}{l}<1,5 \\
<1.5 \\
<1.5 \\
<1.5\end{array}$ \\
\hline $\begin{array}{l}\text { Giolzi } \\
\text { Moro }\end{array}$ & $\begin{array}{c}\text { Bosano } \\
\text { Planargia }\end{array}$ & $\begin{array}{l}\text { Veins and } \\
\text { crustiform }\end{array}$ & $\begin{array}{l}\text { Ranciéite } \\
\text { Ematite } \\
\text { Pyrolusite } \\
\text { Goethite* }\end{array}$ & $\begin{array}{c}50.33 \\
1.54 \\
52\end{array}$ & $\begin{array}{c}1.51 \\
12.58 \\
0.3\end{array}$ & $\begin{array}{c}34.8 \\
61.9 \\
3.4\end{array}$ & $\begin{array}{c}0.25 \\
0.09 \\
0.6\end{array}$ & $\begin{array}{l}15 \\
20 \\
30\end{array}$ & $\begin{array}{c}150 \\
50 \\
<20\end{array}$ & 70 & $<1.5$ \\
\hline Tippiri & $\begin{array}{c}\text { Bosano } \\
\text { Planargia }\end{array}$ & Lentiform & Pyrolusite & $\begin{array}{c}51.7 \\
45.15\end{array}$ & $\begin{array}{l}0.2 \\
2.0\end{array}$ & $\begin{array}{c}3.1 \\
11.9\end{array}$ & $\begin{array}{l}0.05 \\
0.14\end{array}$ & $\begin{array}{l}45 \\
20\end{array}$ & $\begin{array}{l}<20 \\
<20\end{array}$ & $\begin{array}{c}85 \\
110\end{array}$ & $\begin{array}{l}<1.5 \\
<1.5\end{array}$ \\
\hline
\end{tabular}

* Only XRD detected

absence of Mn carbonate minerals is notable because it shows evidence of no significant burial and post-depositional diagenesis in the metalliferous oxide bands. In fact, these minerals have been reported from reducing and high-pH anoxic environments where Mn was first deposited at the sediment surface as tetravalent oxide and then, during diagenesis, carbonate grew at the expense of the oxides. Table 1 shows the most common manganese ore minerals as detected by $\mathrm{X}$ ray diffractometry (XRD) and some chemical data which only concern the main ore-forming elements, and the most significant trace elements. 


\section{The formation of sedimentary manganese}

The genetic study of these sedimentary ores investigated possible sources of ore materials, transportdeposition processes, the paleogeographical conditions and mechanism of ore formation.

\subsection{Metal source}

Bulk-rock geochemical concentrations of manganese are the most plausibile primary source of Mn ions to freshwater and groundwaters of the Logudoro basin. In addition, low-grade, non-economic concentrations of this metal occur in numerous small hydrothermal veins where strong anomalies of Mn are known to exist (Redini, 1940); these examples of mineralization are widespread in the surrounding calcalkaline igneous complex. The Authors support this model of metal release from a "continental" source.

\subsection{Transport}

After the weathering of primary silicates and disseminated mineralizations in the volcanic and volcaniclastic host rocks of the drainage areas, the soluble load of the descending, near-surface, acidic waters would include metals in ionic solution as well as metals adsorbed on clay particles in colloidal suspension. Furthermore, mechanical transport of clastic particles is also quite possible owing to the proximity of the source area. Percolating solutions could have migrated down along the soils and tectonic structures, faults, fractures, conduits, forming a system of local fluid circulation before and during the Basal Miocene deposition. The surface- and ground-waters rich in free oxygen played an important role in the weathering of the rocks above sea level. Under the local paleoclimatic conditions, warm and semiarid climate (Biondi and Filigheddu, 1990), heavy seasonal rainfall resulted in an acidic and oxidizing medium that promoted metal dissolution and transport into lagoons or bays or lacustrine environments for the sedimentation in near- shore, low-energy environments (Maynard, 1983).

A possible type of low-temperature fluid for mobilizing and transporting the metals from the enclosing rocks to the depositional basins is acid groundwater or streams which commonly arise from the oxidation of pyritic orebodies or other sulfide mineralization (Jambor \& Blowes, 1994). These acidic, oxidizing conditions, and high sulfate content, are those which optimise solution transport of both iron and manganese. The principal reactions that generate $\mathrm{H}^{+}$in the surface- water, with subsequent infiltration in the underlying aquifers, are the oxidation of pyrite and other sulfide minerals (Lentz, 2003). However, a variety of acidity attenuation reactions occur in the surroundings geological materials, depending on the availability of acid-consuming mineral phases (e.g., carbonateand other base-containing solids) but the widespread presence of disseminated sulfide mineralizations ensures acid generation in the moving water and simultaneous migration of the metals downstream in the direction of ground-water flow. The solubility of manganese is considerably higher than that of iron for any given Eh and acid $\mathrm{Ph}$ and preferential leaching of this metal with respect to iron may take place because of its larger ionic size and lower ionic potential (Roy, 1981; Sapozhnikov, 1970). Mn-specific soil bacteria may also lead to dissolution and leaching of the element while Mn organic complexes may form by reaction with humic acid in solution.

\subsection{Depositional environment}

The earliest deposition of the host sediments in the initial rifts was probably subaerial, not far from the paleocoastal line, and consisted of conglomerates and arkoses. A first marine transgression fol- 


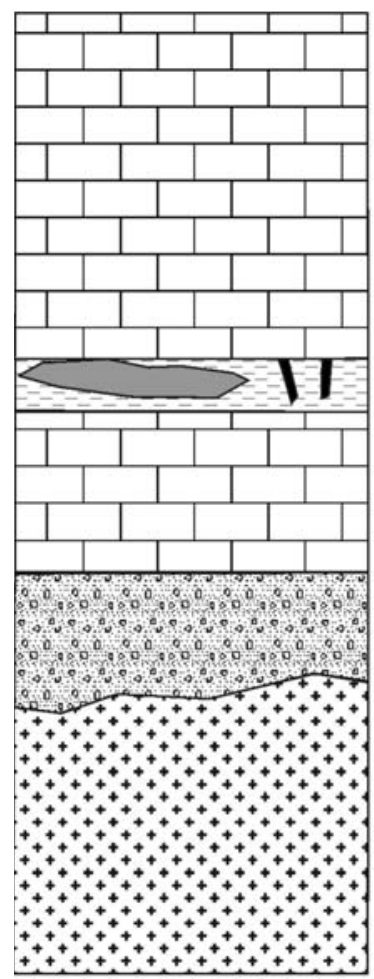

Miocenic carbonatic cover

(Upper Limestone)

Mineralised Siltite beds $(0.5-1 \mathrm{~m})$,

lens and burrows

(Corona de Corvu)

Carbonatic strata

Stratiform conglomerates and arckoses

(earthy mineralization, $1-3 \mathrm{~m}$.).

(S'Alghentalzos)

Bed rock (volcanics)

lowed and deposited coarse- to very fine-grained sediments. Clastic deposition, mainly arenaceous, was slow, with sands and clay minerals being poured into a restricted-circulation water body in shallow marine and beach environments. Although overall conditions were transgressive, Mazzei \& Oggiano (1990) record two main regression and transgression phases during Miocene time. The mineralised lower conglomerate consists of well rounded to sub-angular poorly sorted clasts in a loose coarse sandstone matrix; this conglomerate is rather discontinuous in beach gravels, also consisting at random of feldspathic to impure clayey sands and lens-shaped beds of coarse-grained feldspatic arenite. These conglomerate beds are graded locally and commonly are 0.5 to $3 \mathrm{~m}$ thick. The overlying mineralised rock consists of siltite beds containing remnants of plant material (Fig. 2). The sandstones consist of quartz, feldspar, and volcanic rock fragments, thus may be classified as lithic arkose according to Pettijohn et al. (1972), and represent the first-cycle erosion products of a calc-alkaline volcano-plutonic complex. The sandstone beds associated with the conglomerates are texturally immature, first-cycle arkosic wackes, consisting of poorly sorted quartz and plagioclase feldspar of oligoclase-andesine composition, with accessory alkali feldspar; the smectite-illite matrix content is as high as $30 \%$, thus plotting in the sediment compositional field of arkosic wackes.

\section{Conclusions}

The northwestern part of Sardinia includes zones of stratiform manganese mineralization extending along the margin of the Fossa Sarda rift. Most of these Mn occurrences, although they may be locally concentrated to ore grades, are of subeconomic size. The major control on mineralized sites was the paleotopography, as they are located along ancient coastal lines against basement highs, and re- 
lated to permeable sedimentological features. The weathering and erosion of "fertile" minerals of igneous provenance gives the first link between manganese and the ore occurrences formed in conglomerates in restricted paralic environments.

The main ore-forming event is represented by the arrival of ore constituents released by the continent and transported by gravity-driven ground- and surface-waters in coastal (subaerial to saturated) sediments where the mineralization process took place at very low burial depths. However, restricted locally reducing conditions may indicate temporary subtidal environments or playa flats and lake environments. The syndepositional history was not too complex; most modifications occurred during subaerial exposure or fresh-water environments as shown by the scarcity of marine cements. Synchronous with sedimentation, manganese was precipitated in oxidized low-energy lacustrine (fresh to brackish-water) environments of neutral to alkaline $\mathrm{pH}$ values. The regional paleogeographical and geophysical interpretations of the Logudoro basin and of the broader area of northwestern Sardinia, allowed us to evaluate the regional controls on the localizations of this type of possibly economic manganese mineralizations. Constraints on the size of these occurrences include the lateral variability of the enclosing sedimentary rocks, and their permeabilities. The economic potential of these small but high-grade deposits may be important. Exploration should take into account areas containing regionally high Mn values. First of all, the paleogeographic and structural conditions described in this paper should be confirmed. This may be ascertained through a carefull preliminary geological mapping program followed by the definition of necessary palaeogeographic and structural controls. If these first studies identify a favourable situation, geochemical and geophysical studies, along with the examination of a possible primary source of the metal, should further reduce the exploration area to one or more prospects. Normal detailed exploration methods would then be applied to evaluate the individual ore concentrations.

\section{Acknowledgments}

This study was supported by the Istituto di Geologia Ambientale e Geoingegneria, IGAG del CNR and the Dipartimento di Ingegneria e Tecnologie Ambientali (DIGITA), piazza d'Armi, 09123 Cagliari, Italy.

\section{References}

Biondi E., Filigheddu, P., 1990. A palm fossil closely related to Chamaeropos humilis L. from the Lower Miocene of Sardinia. Giorn. Bot. Ital. 124, 711-724.

Cherchi, M. A., Montadert, L., 1982. Il sistema di rifting Oligo-Miocenico del Mediterraneo occidentale e le sue conseguenze Paleogeografiche sul Terziario Sardo. Mem. Soc. Geol. Ital. 24, 387-400.

Coulon, C., 1977. Le volcanisme calco-alcalin Cénozoicque de Sardaigne (Italie): Pétrographie, géochimie, et genèse des laves andesitiques et des ignimbrites: Signification géodinamique; Thése, Université de Droit, D’Economie et des Sciences D'Aix, Marseille.

Garbarino, C., Grillo, S. M., Marcello, A., Pretti, S., Uras, I., Fiori, M., 1991. First data on Tertiary epithermal occurrences in Sardinia, Italy. Proc. Symp. Braz. Gold 91, Belo Horizonte, 143-150.

Lentz, D.R., 2003. Geochemistry of Sediments and Sedimentary Rocks: Evolutionary Considerations to Mineral Deposit-Forming Environments. Ed. Lentz, D.R., 184pp.

Jambor, J., L., \& Blowes, D.,W., 1994. Short course handbook on environmental geochemistry of sulfide mine-wastes. Waterloo Ontario, May,1994; Ed. Jambor, J., L., \& Blowes, D.,W., 22, 438.

JCPDS File, 1985. Powder diffraction file: Inorganic phases. JCPDS International Centre for Diffraction Data, PA, USA, 998 pp. 
Maynard, J., B., 1983. Geochemistry of Sedimentary Ore Deposits. Springer-Verlag, New York, Heidelberg, Berlin, 305 pp.

Marcello, A., Pretti, S., Valera, P., Fiori, M., 2004. Tertiary manganese occurrences in Sardinia (Italy). Proccedings of the interim IAGOD Conference, Vladivostok, Russia, 487-490.

Martini, I., P., Oggiano, G., and Mazzei, R., 1992. Siliciclastic-carbonate sequences of Miocene grabens of northern Sardinia, western Mediterranea Sea. Sedimentary Geology, 76, 63-78.

Mazzei, R., Oggiano, G., 1990. Messa in evidenza di due cicli sedimentari nel Miocene dell'area di Florinas (Sardegna settentrionale). Atti Soc. Tosc. Sci. Nat., Mem. Seie A., 97, 119-147.

Pettijohn, F., J., Potter, P., E., \& Siever, R., 1972. Sand and sandstones. Springer-Verlag, New York-Heidelberg-Berlin, $618 \mathrm{pp}$.

Redini, R., 1940. Sul wolframio connesso a minerali manganesiferi e sull'età di talune formazioni terziarie della Sardegna settentrionale. Boll. R. Uff. Geol. d'It., 65, 44 pp.

Roy, S. 1981. Manganese Deposits. Academic press., 418 pp.

Sapozhnikov, D., G.,1970. Manganese Deposits of the Soviet Union. Ed. Sapozhnikov, D., G., 522pp. 